\title{
Gendered securitisation: Trump's and Putin's discursive politics of the COVID-19 pandemic
}

\author{
Anna Kuteleva ${ }^{1 *}$ (D) and Sarah J. Clifford ${ }^{2}$ \\ ${ }^{1}$ Faculty of World Economy and International Affairs, National Research University Higher School of Economics, Moscow, \\ Russia and ${ }^{2}$ Department of Political Science, University of Copenhagen, Copenhagen, Denmark \\ ${ }^{*}$ Corresponding author. Email: akuteleva@hse.ru
}

(Received 26 September 2020; revised 24 February 2021; accepted 24 February 2021; first published online 1 March 2021)

\begin{abstract}
This article presents a study of the discursive politics of the COVID-19 outbreak in the United States and Russia from its early onset to 30 April 2020. We examine how official securitisation discourses in the two countries draw on gendered constructions of national identity and discuss what linkages and potential implications they have for the state, its policy, and its society. Our analysis shows that both the US President Donald Trump and Russia's President Vladimir Putin instrumentalise hierarchical gendered identities to securitise COVID-19. They mobilise gendered narratives, imageries, and practices to affirm particular understandings of the threat and create a homogeneous national 'we', portraying themselves as its guardians.
\end{abstract}

Keywords: COVID-19; Securitisation; Feminist Methodologies; National Identity

\section{Introduction}

It is already all too apparent around the world that COVID-19 is dangerous. In the modern history of natural disasters, this virus will have few rivals. States continue to wrestle with how best to respond to the COVID-19 pandemic, but its securitisation is already universal. ${ }^{1}$ The mechanisms of securitisation are socially and culturally specific. Simply put, all states securitise COVID-19 but each state does so in a unique way. By identifying the pandemic as an existential security threat, national decision-makers respond to it from both operational and normative perspectives. In doing so, they actualise and perform some national identities, while excluding or silencing others.

We scrutinise this process by drawing on the cases of the United States and Russia. Experiences of these two states matter because they both play an active role in the evolving global discursive politics of the COVID-19 pandemic and consistently appear among the top ten most affected countries. Moreover, there is a divergence between the resurgence of the Cold War-style geopolitical confrontation between the West and Russia and the diplomatic 'bromance' between the US President Donald Trump and Russia's President Vladimir Putin. ${ }^{2}$ These two politicians

\footnotetext{
${ }^{1}$ See, for example, Hannah van Kolfschooten and Anniek de Ruijter, 'COVID-19 and privacy in the European Union: A legal perspective on contact tracing', Contemporary Security Policy, 41:3 (2020), pp. 478-91; Adam Ferhani and Simon Rushton, 'The international health regulations, COVID-19, and bordering practices: Who gets in, what gets out, and who gets rescued?', Contemporary Security Policy, 41:3 (2020), pp. 458-77; Xiaofeng Liu and Mia M Bennett, 'Viral borders: COVID-19's effects on securitisation, surveillance, and identity in Mainland China and Hong Kong', Dialogues in Human Geography, 10:2 (2020), pp. 158-63.

${ }^{2}$ Our study was conducted in May to June 2020, when Donald Trump was the president of the United States. All references to Trump's presidency should be taken as in the past tense.

(c) The Author(s) 2021. Published by Cambridge University Press on behalf of the British International Studies Association. This is an Open Access article, distributed under the terms of the Creative Commons Attribution-NonCommercial-ShareAlike licence (http://creativecommons.org/licenses/by-nc-sa/4.0/), which permits non-commercial re-use, distribution, and reproduction in any medium, provided the same Creative Commons licence is included and the original work is properly cited. The written permission of Cambridge University Press must be obtained for commercial re-use.
} 
present themselves as alpha males promising to make their nations 'great again'. As Sarah Ashwin and Jennifer Utrata point out, both of them attract immense international attention, and hence 'these hypermasculine performances are not merely national in scope, but shape other places in our globalized world'. ${ }^{3}$

Building our analysis on feminist methodologies, ${ }^{4}$ we examine how Trump and Putin instrumentalise hierarchical gendered identities to enforce the securitisation of COVID-19. Our analysis shows that both Trump and Putin draw heavily on projections of gendered power to maximise the effect of their securitisation moves and mobilise diverse gendered narratives, imageries, and practices to construct the meaning of the threat. These performances of securitisation set standards of appropriateness and legitimise certain kinds of foreign policy responses to the pandemic while silencing others or presenting them as ineffective. In this sense, we contribute to the discussion of COVID-19 politics by exploring gendered discursive practices that enable the move from 'normal' politics to the domain of emergency and exception or, as Andreas Kalyvas puts it, to the 'politics of the extraordinary'.

This areticle is organised into three sections. The first section outlines our approach to securitisation and the methodology of our study. The following two sections examine the dynamics of securitising COVID-19 in the United States and Russia, indicating differences and similarities in their discursive strategies. The conclusions raise and bring to the fore questions not only regarding political responses to the COVID-19 pandemic but also concerning the nature and outcomes of the securitisation process.

\section{Theoretical background and methodology}

Securitisation is 'a set of interrelated practices and the processes of their production, diffusion, and reception/translation that bring threats into being. ${ }^{6}$ The concept of securitisation opens up a way to denaturalise the framing of certain events, issues, things, or people as posing existential threats to states and societies. ${ }^{7}$ Many scholars also use it to call into question the givenness of the differential categories of 'security' and 'insecurity'. ${ }^{8}$ Scholars who examine the politics of diseases, however, often deal with threats that are not talked into being. For example, using the case of HIV/AIDS, Colin McInnes and Simon Rushton argue ${ }^{9}$ that to question the 'reality' of the threat posed by a disease is 'both morally indefensible and empirically absurd'.

\footnotetext{
${ }^{3}$ Sarah Ashwin and Jennifer Utrata, 'Masculinity restored? Putin's Russia and Trump's America', Contexts, 19:2 (2020), pp. 16-21 (p. 17).

${ }^{4}$ Charlotte Hooper, Manly States: Masculinities, International Relations, and Gender Politics (New York: Columbia University Press, 2001); Bonnie Mann, 'How America justifies its war: A modern/postmodern aesthetics of masculinity and sovereignty', Hypatia, 21:4 (2006), pp. 147-63; Laura Sjoberg and Caron E. Gentry, Women, Gender, and Terrorism (Georgia: The University of Georgia Press, 2011); Sara Ahmed, The Cultural Politics of Emotion (Edinburgh: Edinburgh University Press, 2014).

${ }^{5}$ Andreas Kalyvas, Democracy and the Politics of the Extraordinary (Cambridge: Cambridge University Press, 2008).

${ }^{6}$ Thierry Balzacq, 'Preface', in Thierry Balzacq (ed.), Understanding Securitisation Theory: How Security Problems Emerge and Dissolve (New York: Routledge, 2010), pp. xiii-xiv.

${ }^{7}$ See, for example, Rita Dhamoon and Yasmeen Abu-Laban, 'Dangerous (internal) foreigners and nation-building: The case of Canada', International Political Science Review, 30:2 (2009), pp. 163-83; Siobhan Byrne, 'Framing post-9/11 security: Tales of state securitization and of the experiences of Muslim communities', in Bruno Charbonneaeu and Wayne S. Cox (eds), Locating Global Order: American Power and Canadian Security after 9/11 (Vancouver: University of British Columbia Press, 2010), pp. 167-82; David Moffette and Shaira Vadasaria, 'Uninhibited violence: Race and the securitization of immigration', Critical Studies on Security, 4:3 (2016), pp. 291-305; Matthew Kearns, 'Gender, visuality and violence: Visual securitization and the 2001 war in Afghanistan', International Feminist Journal of Politics, 19:4 (2017), pp. 491-505.

${ }^{8}$ See, for example, Jef Huysmans, 'International politics of insecurity: Normativity, inwardness and the exception', Security Dialogue, 37:1 (2006), pp. 11-29; Sarah Bertrand, 'Can the subaltern (in)securitize? A rejoinder to Claudia Aradau', European Journal of International Security, 3:3 (2018), pp. 306-09.

${ }^{9}$ Colin McInnes and Simon Rushton, 'HIV/AIDS and securitization theory', European Journal of International Relations, 19:1 (2013), pp. $115-38$ (p. 121).
} 
Similarly, the danger that COVID-19 presents is all too real. More than two million people are known to have died from COVID-19 as of January 2021. A year has passed since the virus was discovered, yet hospitals are still buckling under a torrent of COVID-19 patients and the routines of daily life remain interrupted for billions worldwide. Importantly, COVID-19 is an endemic that will stay with us for some time.

In this context, the concept of securitisation is used not to question the threat that COVID-19 poses for the survival and wellbeing of people around the world but to elucidate how political actors reconstruct understandings of COVID-19 via securitising moves and what different pathways of response become appropriate as a result of these moves. Consequently, we treat securitisation as 'a sustained strategic practice aimed at convincing a target audience to accept, based on what it knows about the world, the claim that a specific development ... is threatening enough to deserve an immediate policy to alleviate it'. ${ }^{10}$ Adopting Thierry Balzacq's approach, ${ }^{11}$ we do not problematise the fact of securitisation but critically examine how and with what effect discursive politics of securitisation works. Specifically, we are interested in how state actors that dominate discursive politics of (in)security performatively build upon established and context-specific gendered identities in the process of securitisation.

The very notion of national security is gendered inasmuch as it is grounded in the gendered nature of the state and state practices. ${ }^{12}$ This entails that power operates via the (discursive) construction and reconstruction of hierarchical hybrid gendered identities with the intent to enforce certain security interests on domestic and international levels. As Charlotte Hooper emphasises, 'it is a commonplace observation that international relations reflect a world of men in that they influence international affairs through their physical capacities, through (masculinist) practices at the institutional level, and through the symbolic links between masculinity and power.' ${ }^{13}$ Consequently, Hooper argues that masculinity is hegemonic, meaning that specific forms of masculinity dominate over all other gendered identities, including other masculinities. These relatively stable hegemonic configurations of gender practices exemplify 'the currently accepted answer to the problem of the legitimacy of patriarchy, which guarantees (or is taken to guarantee) the dominant position of men and the subordination of women'. ${ }^{14}$ Following this logic, hegemonic masculinity is instrumental in constructing threat and danger as well as performing security.

Hegemonic masculinity takes on many forms depending on different social, political, and economic settings. In this sense, it is dynamic and context-specific. Each state's potential to claim the status of the masculine hegemon in the international arena depends on its performance among other states and its ability to repel threats both domestically and internationally. National leaders actualise and perform hegemonic masculinities to convince audiences at home and abroad that they are able to combat a threat. Masculinised imageries allow national leaders to present security as a result of their rule, making that rule legitimate. In effect, performing a state's hegemonic masculinity ties directly to its leader's ability to securitise a threat. Importantly, the process of securitising not only represents but also is reproductive of hegemonic masculinity of the state. National leaders rearticulate it through the narratives and imageries evoked in their securitising moves.

Drawing on this theoretical framework, we examine how national leaders in the United States and Russia reconstitute hegemonic masculinities within the 'threat-defence' logic of responses to the COVID-19 outbreak. Our sample includes statements on COVID-19 made by Trump and

\footnotetext{
${ }^{10}$ Thierry Balzacq, 'The three faces of securitization: Political agency, audience and context', European Journal of International Relations, 11:2 (2005), pp. 171-201 (p. 173).

${ }^{11}$ See also Thierry Balzacq, 'Securitization theory: Past, present, and future', Polity, 51:2 (2019), pp. 331-48.

${ }^{12}$ See, for example, Johanna Kantola, 'The gendered reproduction of the state in international relations', The British Journal of Politics and International Relations, 9:2 (2007), pp. 270-83; Jonathan D. Wadley, 'Gendering the state: Performativity and protection in international security', in Laura Sjoberg (ed.), Gender and International Security: Feminist Perspectives (New York: Routledge, 2010), pp. 38-58.

${ }^{13}$ Hooper, Manly States: Masculinities, p. 79.

${ }^{14}$ Raewyn Connell, Masculinities (Berkeley: University of California Press, 2005), p. 77.
} 
Putin from the early onset of the current global public health crisis to 30 April 2020. This time frame covers an important period in the discursive formation of the COVID-19 outbreak in both the United States and Russia as a matter of national security. It allows us to examine securitisation in the making rather than focus on the audience's acceptance of securitising moves. In other words, the chosen time frame restricts our analysis to the very first performative attempts at securitising the pandemic.

The core data collection includes 126 official statements, speeches, interviews, and press briefings produced by Trump (81) and Putin (45). ${ }^{15}$ Our analysis centres on the two leaders and does not include other national and international securitising actors. However, to fill in some contextual gaps and provide a more nuanced understanding of the discursive politics of securitisation, we also look at statements from US Vice President Michael Pence, US Secretary of State Michael Pompeo, as well as Russia's Prime Minister Mikhail Mishustin and representatives of the Ministry of Foreign Affairs. These actors are at the forefront of their respective state's responses to the pandemic but do not exercise a discursive agency by producing independent meanings. Instead, their statements on COVID-19 expand and reinforce Trump's and Putin's discourses. The final dataset contains 239 textual documents (157 in English and 82 in Russian). ${ }^{16}$

To structure our analysis, we formulate an overarching investigative question: How do national leaders in the United States and Russia construct their states and nations as well as Others in relation to the COVID-19 pandemic? Further, we divide this question into four simple and clear operational questions:

- Definition of the subject: How is the COVID-19 outbreak constructed as a national security challenge?

- Definition of actors (Self): Who are 'we' in relation to the pandemic?

- Definition of actors (Other): Who are 'they' in relation to the pandemic?

- Definition of action: What are 'we' going to do with the pandemic?

While we focus primarily on how national leaders securitise the COVID-19 outbreak by talking about it, we recognise that not all (in)securities are, or can be, socially constructed via series of speech acts and that the discursive politics of securitisation is not limited to words. ${ }^{17}$ To capture securitisation in the making and performances of hegemonic masculinity that sustain it, we explore not only the words of national leaders but also communication practices and imaginaries that they use to reinforce these words.

The outlined analytical framework allows us not only to provide a nuanced perspective on the discursive politics of the pandemic but also to explain how and with what effect its securitisation triggers a reconstruction of American and Russian hegemonic masculinities. Further, we show

\footnotetext{
${ }^{15}$ It is undeniable that social media's impact on US politics continues to grow. In particular, Twitter took on a new meaning as Trump started to use it as his personal megaphone to reach US citizens, members of the media, and even leaders of other countries. However, for the purpose of this research, we choose to focus on Trump's official statements only. Firstly, we wanted to have comparable datasets. Trump mentions COVID-19 on Twitter for the first time on 24 January 2020 and produces 640 tweets in the three subsequent months that are directly related to COVID-19. In contrast, given the authoritarian nature of Russia's politics, Putin's communication with Russian citizens is significantly less dynamic, extensive, and versatile. Secondly and importantly, we believe that Trump's Twitter engagement during the pandemic is a significant phenomena in itself and its influence on (de)securitising COVID-19 in the United States as well as internationally deserves a systematic independent study.

${ }^{16} \mathrm{We}$ analyse all Russian texts in their original language to avoid losing contextual or culturally specific meanings and expressions. We only translate the excerpts used for illustration into English.

${ }^{17}$ See, for example, Lene Hansen, 'The Little Mermaid's silent security dilemma and the absence of gender in the Copenhagen School', Millennium, 29:2 (2000), pp. 285-306; Michael C. Williams, 'Words, images, enemies: Securitization and international politics', International Studies Quarterly, 47:4 (2003), pp. 511-31; Didier Bigo, 'The (in)securitization practices of the three universes of EU border control: Military/Navy-border guards/police-database analysts', Security Dialogue, 45:3 (2014), pp. 209-25.
} 
how this process is embedded in and sustained by gendered structures of power that pervade the international system and shape relations between the United States and Russia as well as their interactions with other countries (specifically, with China) during the pandemic.

\section{Trump's performance of sovereign masculinity amid the COVID-19 crisis}

In a paralleled vein to feminist discussions of 9/11, COVID-19 produces what Bonnie Mann calls the 'unmanning' of America. ${ }^{18}$ Mann details how sovereignty is a 'style of national masculinity' with any violation of a nation's borders resulting in its figurative demasculinisation. ${ }^{19}$ Accordingly, the pandemic challenges the American doctrines of absolute sovereignty, invulnerability, and global hegemony. To counter this threat, Trump reframes it not as a public health dilemma but as a threat to the nation's security and hegemonic masculinity. In this setting, COVID-19 presents a direct threat to the national body that is innately gendered.

On 4 February Trump securitises COVID-19. ${ }^{20}$ However, in January and February, Trump struggles with fully committing to the securitising move and vacillates between securitising and desecuritising the spread of COVID-19. At first, Trump frames the virus only as a 'potential threat' contained in China. ${ }^{21}$ Simultaneously, he assures his audience that '[o]ur country is prepared for any circumstances' and that 'there's no reason to panic at all' as the possibility of exposure and mortality to the American nation 'remain[s] low'.22 It is not until 13 March that Trump constructs COVID-19 as an existential crisis and 'national emergency', one that not only threatens the nation's health but also has the power to obstruct its sovereignty and security. ${ }^{23}$

As specified by Trump, one of the existential challenges of the pandemic is that the United States will face the 'public health consequences of a mass uncontrolled cross-border movement'. ${ }^{24}$ Starting from the presidential campaign in 2015, Trump persistently pushes migration out of the domain of 'normal politics'. As the pandemic unfolds, he builds upon the image of the othered and villainised migrant to redefine COVID-19 not only as a health hazard but also as a security threat that can compromise the nation's sovereignty. Trump personifies these fears in undocumented migrants who potentially carry COVID-19. This extra discursive layer highlights how the perceived threat to America's sovereignty elevates the virus from a public health dilemma to a national security crisis through the processes of Othering. For example, he emphasises that

they threaten to create a perfect storm that would spread the infection to our border agents, migrants, and to the public at large. Left unchecked, this would cripple our immigration system, overwhelm our healthcare system, and severely damage our national security. ${ }^{25}$

As a response, Trump affirmatively declares that 'we're not going to let that happen'. ${ }^{26}$ Sara Ahmed explains such a discursive reconstruction as an attempt to monopolise and 'eliminate

\footnotetext{
${ }^{18}$ Mann, 'How America justifies its war', p. 153.

${ }^{19}$ Ibid., p. 155.

${ }^{20}$ Donald Trump, 'Remarks by President Trump in the State of the Union Address', The White House, Washington, DC, 4 February 2020.

${ }^{21}$ Donald Trump, 'Remarks by President Trump, Vice President Pence, and Members of the Coronavirus Task Force in Press Conference', The White House, Washington, DC, 27 February 2020; Donald Trump, 'Remarks by President Trump, Vice President Pence, and Members of the Coronavirus Task Force in Press Conference', The White House, Washington, DC, 29 February 2020.

${ }^{22}$ Trump, 27 February 2020.

${ }^{23}$ Donald Trump, 'Remarks by President Trump, Vice President Pence, and Members of the Coronavirus Task Force in Press Conference', The White House, Washington, DC, 13 March 2020.

${ }^{24}$ Donald Trump, 'Remarks by President Trump, Vice President Pence, and Members of the Coronavirus Task Force in Press Conference', The White House, Washington, DC, 20 March 2020.

${ }^{25}$ Ibid, emphasis added.

${ }^{26}$ Ibid.
} 
the source of fear' - a move by the state to control the uncontrollable through asserting selfdetermination and containment. ${ }^{27}$ In other words, Trump portrays the United States as no longer fearful but as a nation that is mobilised to repel the dangerous Other. This construction also frames Trump and his administration as the protectors of the nation ('we') from the existential threat ('they') by concurrently securitising and desecuritising COVID-19. Trump's narrative does not alleviate the threat of the pandemic but, counterintuitively, dispels notions of fear and security to discursively embolden his masculine command over the nation.

COVID-19 is not only embodied by the undocumented migrant but is also personified through a multiplicity of Others. To shift the blame for the harms of the COVID-19 outbreak, Trump fixates on China and racialises the pandemic as a 'Chinese' threat. Since 21 January, Trump obsessively emphasises that COVID-19 'comes from China' and should be regarded as the 'Chinese virus' or 'Wuhan virus'. ${ }^{28}$ Restricting international travel from China to the United States, Trump labels his executive order the 'China ban', stating that 'China, you can't come in. I'm sorry. ${ }^{29}$ While the United States evades an attack from the virus by shutting its borders and taking strong actions, China is presented as weak and incapable. According to Trump, the COVID-19 outbreak 'could have been stopped in China, before it started, and it wasn't' and now 'the whole world is suffering because of it'. ${ }^{30}$ China is portrayed as a soft nation because of its permeable borders, passivity, and ineffective leadership. The feminine softness makes it not only vulnerable but also dangerous. By differentiating and separating the nation from the pandemicstricken Others, Trump does not allow the insecurity of COVID-19 to feminise the United States and, in turn, (re)secures America's masculinity.

By framing COVID-19 as a destabilising force to the United States' masculinity, Trump mobilises the nation around three gendered narratives to perform and actualise American hegemony: the gendered construction of the national 'we', militarisation, and displays of the United States' economic omnipotence. These three discursive formations function as applicators to deconstruct how the nation is mobilised to repel the threat. Building on this logic, Trump's performances of certain hegemonic traits demonstrate how gender practices become a securitising tool utilised by national leaders in times of crisis.

The performative values that the American state believes its citizens personify are embedded in these gender practices. In Trump's words, Americans are those who 'do not despair'. ${ }^{31} \mathrm{He}$ argues that 'we do not give in to fear' and 'we pull together, we persevere, and we overcome, and we win'. ${ }^{32}$ Americans 'sacrifice together', ${ }^{33}$ but, as Ahmed puts it, the nation is presented as winning by 'refusing to transform its vulnerability and wounds ... into an affective response of fear' ${ }^{34} \mathrm{~A}$ response that is premised on exemplifying the masculine characteristics of 'valour', aggression, and determination in times of combat. These characteristics frame the nation as being militarised and in a perpetual state of conflict that will not dissipate until the threat has been vanquished:

As our citizens persevere through this present challenge, we're renewing American unity and we're replenishing American will and we are witnessing new American valor each and every

\footnotetext{
${ }^{27}$ Ahmed, The Cultural Politics of Emotion, p. 73.

${ }^{28}$ See, for example, Donald Trump, 'Remarks by President Trump, Vice President Pence, and Members of the Coronavirus Task Force in Press Conference', The White House, Washington, DC, 18 March 2020; Donald Trump, 'Remarks by President Trump, Vice President Pence, and Members of the Coronavirus Task Force in Press Conference', The White House, Washington, DC, 14 April 2020.

${ }^{29}$ Trump, 14 April 2020.

${ }^{30}$ Donald Trump, 'Remarks by President Trump, Vice President Pence, and Members of the Coronavirus Task Force in Press Conference', The White House, Washington, DC, 18 April 2020.

${ }^{31}$ Donald Trump, 'Remarks by President Trump, Vice President Pence, and Members of the Coronavirus Task Force in Press Conference', The White House, Washington, DC, 1 April 2020.

${ }^{32}$ Ibid.

${ }^{33}$ Trump, 18 March 2020.

${ }^{34}$ Ahmed, The Cultural Politics of Emotion, p. 73.
} 
day. We see it every day. The daring and determination of our people in this crisis reminds us that no matter how hard it gets, no matter what obstacles we must overcome, Americans will keep on fighting to victory and we will secure the glorious future that our citizens so richly deserve, especially after going through this nightmare, this evil beast. ${ }^{35}$

Here, Trump constructs the notion of an 'internal strength' that the American populace epitomises - one that transforms the emotions of fear and insecurity into the imagery of mobilisation and collective triumph. ${ }^{36}$ In this framework, the nation escapes potential feminisation by acting as a wilful subject and taking command of the pandemic. To further denote a sense of control and agency, Trump uses active verbs to place the United States not as a passive, feminised observer but as an active, masculine participant. By positioning the United States as one that is 'renewing', 'replenishing', and 'witnessing', Trump construes the nation as actively mobilising and hence, enacting its masculinity against COVID-19.

To perform the state's hegemonic masculinity, Trump also militarises the society. Drawing upon established gendered identities, the Trump administration evokes a series of securitising moves to militarise COVID-19. ${ }^{37}$ As early as 15 March, Trump argues that the United States 'deployed over a thousand officers in support of the coronavirus missions', reframing the pandemic not as an emergency managed by health professionals but one controlled by the military that will 'defend our homeland during this crisis'. ${ }^{38}$ In this framework, the nation's military capabilities are constructed as a source of security, a physical reassertion of its masculinised control and dominance. Here, Trump touts the desirability of the military, stating that

[o]ur great military is operating at 100 per cent during this crisis and thousands of troops are deployed alongside of civilians in the COVID hotspots, as you know. You see them all over. I spoke - when I spoke with Governor Cuomo, and when I spoke to Gavin Newsom, and many of the other governors, they wanted to know if we could have some military help with the medical, and we - we gave it to them. ${ }^{39}$

This quote presents the military as the masculinist protector of the nation with Governors jockeying for its aid while simultaneously framing it as a pervasive and saturating force who is 'all over'. The military's spreading encroachment across all vectors of society assures Trump's audience of the United States' ever-growing control over the virus, and in turn, paints the military as the reason for the nation's success. As a result, Trump hails his response to the pandemic as 'a tremendous victory', 'thanks to our all-out military operation and the extraordinary devotion of our people' as 'we believe we will experience far fewer deaths than even the optimistic projection'. 40

\footnotetext{
${ }^{35}$ Donald Trump, 'Remarks by President Trump, Vice President Pence, and Members of the Coronavirus Task Force in Press Conference', The White House, Washington, DC, 8 April 2020.

${ }^{36}$ Ahmed, The Cultural Politics of Emotion, p. 78.

${ }^{37}$ The American military reflects the ongoing gendered competition between states for superiority, where the success of a nation's troops symbolically affirms the nation's masculinity and its association with certain sex-based characteristics, in comparison with the other nations at war. As the military and its core traits of prowess, violence, bravado, and domination often represent the 'fullest expression of masculinity', the military becomes a performative feature used to demonstrate the masculinity of the nation during times of crisis (Hooper, Manly States, p. 81).

${ }^{38}$ Donald Trump, 'Remarks by President Trump, Vice President Pence, and Members of the Coronavirus Task Force in Press Conference', The White House, Washington, DC, 15 March 2020; Trump, 20 March 2020.

${ }^{39}$ Donald Trump, 'Remarks by President Trump, Vice President Pence, and Members of the Coronavirus Task Force in Press Conference', The White House, Washington, DC, 22 April 2020.

${ }^{40}$ Donald Trump, 'Remarks by President Trump, Vice President Pence, and Members of the Coronavirus Task Force in Press Conference', The White House, Washington, DC, 16 April 2020; Donald Trump, 'Remarks by President Trump, Vice President Pence, and Members of the Coronavirus Task Force in Press Conference', The White House, Washington, DC, 24 April 2020.
} 
In tandem with the physical deployment of the military, Trump's rhetoric is imbued with militarised references. Trump constructs the pandemic as a figurative battlefield, one that parallels 'a World War, or a World War One or Two or something' as it is 'a war all unto itself. ${ }^{41}$ To align with this imagery, military hospitals are deployed to New York and Los Angeles, 'frontline workers' are reconceptualised as heroic, selfless soldiers falling in the line of duty, and even ordinary citizens are viewed as making their patriotic contribution to the nation by 'fighting this battle from home'. ${ }^{42}$

Not only does Trump construct the pandemic as an 'all-out war' but he places himself at the centre of society's militarisation: 'I'm a wartime president. This is a war. This is a war. A different kind of war that we've ever had. ${ }^{43}$ Here, Trump figuratively takes control of all militarised activities intended to protect the population by using the personal pronoun 'I'. As an extension of this militarised paternalism, Trump's reluctance to count the casualties of this 'war' creates ambiguity and disillusionment that alters what Christine Sylvester calls the 'perceptions of American war capabilities'. ${ }^{44}$ Following this logic, Trump often refuses to broadcast the statistics of American mortality and case rates. However, when discussing these statistics discreetly, multiple members of Trump's team utilise dehumanising tactics by referring to those who passed away from COVID-19 as having 'expired' - a term that more frequently refers to food past its due date rather than the loss of a citizen. ${ }^{45}$ Trump also deploys these discursive tactics to create a façade of militarised success that is further bolstered by notions of paternalistic protection as well as hegemonic and charismatic leadership. For instance, when prompted by reporters in multiple press briefings to discuss the number of cases, Trump belligerently dismisses their questions as 'nasty', 'really bad reporting', and 'sensationalism'. ${ }^{46}$ These discursive tactics expose Trump's lack of transparency as an effort to give the American people a renewed sense of 'hope' and safeguard them from the brutal truth of 'war'. ${ }^{47}$ Once again, such militarised responses to the pandemic place Trump not only within the centrefold of controlling America's military activities but also in the role of hegemonic protector.

While Trump's role as the nation's protector rests upon his position as the Commander in Chief, his legitimation strategy also relies heavily on the United States' economic capacity. Unlike his two predecessors, Trump's reign has conjured a blatant reframing of previously exemplified American masculine norms. From George W. Bush's indelible hyper-sexualised bravado ${ }^{48}$ to Barack Obama's familial paternalism, ${ }^{49}$ Trump's form of physical masculinity leaves much to be desired. As a result, the construction of Trump's masculinity and, in the consortium, his legitimacy revolves not around his prominent physical characteristics but instead around his success as an entrepreneur. ${ }^{50}$

\footnotetext{
${ }^{41}$ Donald Trump, 'Remarks by President Trump, Vice President Pence, and Members of the Coronavirus Task Force in Press Conference', The White House, Washington, DC, 5 April 2020.

${ }^{42}$ Donald Trump, 'Remarks by President Trump, Vice President Pence, and Members of the Coronavirus Task Force in Press Conference', The White House, Washington, DC, 3 April 2020.

${ }^{43}$ Donald Trump, 'Remarks by President Trump, Vice President Pence, and Members of the Coronavirus Task Force in Press Conference', The White House, Washington, DC, 22 March 2020; Trump, 22 April 2020.

${ }^{44}$ Christine Sylvester War as Experience: Contributions from International Relations and Feminist Analyses (New York: Routledge, 2013), p. 67.

${ }^{45}$ Michael R. Pence, 'Remarks by Vice President Pence at a Coronavirus Briefing with Diagnostic Lab CEOs', The White House, Washington, DC, 4 March 2020.

${ }^{46}$ Donald Trump, 20 March 2020.

${ }^{47}$ Ibid.

${ }^{48}$ Kevin Coe, David Domke, Meredith M. Bagley, Sheryl Cunningham, and Nancy Van Leuven, 'Masculinity as political strategy: George W. Bush, the "war on terrorism", and an echoing press', Journal of Women, Politics \& Policy, 29:1 (2007), pp. 31-5.

${ }^{49}$ Bonnie Mann, Sovereign Masculinity: Gender Lessons from the War on Terror (Oxford: Oxford University Press, 2014).

${ }^{50}$ Pierce Dignam, Douglas Schrock, Kristen Erichsen, and Benjamin Dowd-Arrow, 'Valorizing Trump's masculine self: Constructing political allegiance during the 2016 presidential election', Men and Masculinities (2019), pp. 1-26.
} 
On multiple occasions, Trump draws on his economic success over the three years as president to demonstrate his capacity to rule. He states that 'nobody has ever done anything like what we were able to do' ${ }^{51}$ and forcefully appropriates this achievement:

I think you're going to have a recovery. Look, I built - they were just telling me inside, and it's fact - I built the greatest economy - with the help of 325 million people, I built the greatest economy in the history of the world. And one day, because of something that should have never been allowed to happen, we had to close our country, we had to close our economy. ${ }^{52}$

Such assertions portray Trump not only as a legitimate and successful leader of the United States but, more importantly, as the one responsible for maintaining its position as the economic powerhouse and global hegemon. As the latter quote exemplifies, Trump excessively utilises the first personal pronoun ('I'), which allows him to embody the success of the nation. As the American economy slipped into one of the worst downturns since the Great Depression, Trump claims that 'I had to turn it off in order to get to a point where we are today. ${ }^{\text {'5 }}$

While claiming responsibility for the economic safety of the nation, Trump also assures his audience that Americans will 'help countries around the world as well' because 'the whole world is watching' them. ${ }^{54}$ The narrative of Trump's leadership par excellence produces an image of the United States as the supreme leader in the fight against COVID-19, whereas other countries 'aren't highly sophisticated' and represent failures. ${ }^{55}$ For example, Trump contrasts the United States' rate of COVID-19 testing with that of other countries:

We are way ahead on testing. We are the best in the world on testing. We've tested much more than anybody else, times two - or every country combined. We've tested more than every country combined. ... The quality of our tests is the best and the number is the best. ${ }^{56}$

These multiple superlatives and assertions that the United States is 'first' on one or another measure enable Trump to reinforce a masculine fiction of conquest and triumph. In this framework, the pandemic becomes a platform for the United States to demonstrate and maintain its innovative capacity and supremacy.

Similarly, other top-level members of Trump's administration extend the narrative of American omnipotence. As a case in point, Mike Pompeo reminds the media that 'a lot of countries are asking us for assistance and a lot of countries have received assistance', assuring that the United States has 'of course, done the right thing' ${ }^{57}$ However, he instantly highlights that the United States will be 'an enormous force for good' in other countries and regions only after it provides for itself:

We've made sure we had the resources for our own people, but as the American greatness as American power and American commercial prosperity continues to grow, we're building out - we're getting not only ventilators but all of the equipment that the world will need. ${ }^{58}$

\footnotetext{
${ }^{51}$ Donald Trump, 'Remarks by President Trump, Vice President Pence, and Members of the Coronavirus Task Force in Press Conference', The White House, Washington, DC, 27 April 2020.

${ }^{52}$ Ibid.

${ }^{53}$ Ibid.

${ }^{54}$ Trump, 8 April 2020; Trump, 27 April 2020.

${ }^{55}$ Trump, 1 April 2020.

${ }^{56}$ Donald Trump, 'Remarks by President Trump, Vice President Pence, and Members of the Coronavirus Task Force in Press Conference', The White House, Washington, DC, 28 April 2020.

${ }^{57}$ Donald Trump, 'Remarks by President Trump, Vice President Pence, and Members of the Coronavirus Task Force in Press Conference', The White House, Washington, DC, 27 February 2020.

${ }^{58}$ Michael R. Pompeo, 'Secretary Michael R. Pompeo With Steve Doocy, Ainsley Earhardt, and Brian Kilmeade of FOX and Friends', US Department of State, 29 April 2020.
} 
While Trump and Pompeo make it clear that the United States will take care of itself first, they continue to represent the nation as the world's saviour and protector of the weak. This notion is explicitly rhetorical. Although both figures elevate COVID-19 to a 'global threat', ${ }^{59}$ it is clear that the United States is isolated. Rather than binding together as a universal front and leading the world to victory, Trump and his most prominent team members continually denounce the work of both other nations and international organisations, portraying the United States as individually successful in comparison. In turn, the fight against COVID-19 is framed not as a fight for global immunity and humankind but as a competition over who is going to defeat the threat first.

\section{Putin's paternalistic masculinity and discursive politics of the COVID-19 securitisation}

Putin mentions COVID-19 publicly for the first time on 29 January $2020 .{ }^{60}$ Between 1 January and 29 February, he refers to COVID-19 briefly six times but does not explicitly frame it as a national security challenge. Finally, he recognises it as a threat to Russia only in early March, when 16 neighbouring countries report cases. Throughout March and April, he compares Russia's COVID-19 response to a battle several times ${ }^{61}$ and calls the virus an 'enemy' once. ${ }^{62}$ Otherwise, he consistently frames the COVID-19 outbreak as a challenge rather than a combat. Moreover, reacting to Angela Merkel's, Emmanuel Macron's, and other national leaders' statements, ${ }^{63}$ Putin criticises comparisons of the pandemic to war as well as the use of 'military expressions' in its discussion in general. ${ }^{64}$ For example, placing the current crisis in a historical context, he argues that 'the whole world faces such difficult challenges for the first time after World War II' but immediately specifies that it cannot be equated with the devastation of the war and such a comparison is both misleading and inappropriate. ${ }^{65}$ Unlike Trump who defines COVID-19 as 'a great national struggle', an 'invisible enemy', and the 'Chinese virus', ${ }^{66}$ Putin hardly brings up any figurative expressions to define COVID-19. He consistently uses dry official terminology: the 'coronavirus infectious disease' or the 'coronavirus infection'. ${ }^{67}$ Most often he calls the COVID-19 outbreak 'this situation', avoiding words 'pandemic' and 'epidemic'. 68 Consequently, Putin demilitarises COVID-19.

At the same time, Putin does not downplay the dangers of the virus. He describes it as an unpredictable threat, emphasising that it is impossible to make accurate forecasts and thus

\footnotetext{
${ }^{59}$ Michael R. Pompeo, 'Secretary Michael R. Pompeo with Tony Perkins of Washington Watch U.S. Department of State', 12 February 2020.

${ }^{60}$ Vladimir Putin, 'Soveshchaniye o merakh po bor'be s rasprostraneniyem koronavirusa v Rossii [Meeting on Measures to Combat the Spread of Coronavirus in Russia]', Moscow, Kremlin, 29 January 2020.

${ }^{61}$ See, for example, Vladimir Putin, 'Obrashcheniye $\mathrm{k}$ grazhdanam Rossii [Address to the Citizens of Russia]', Novo-Ogaryovo, 25 March 2020; Vladimir Putin, 'Vstrecha s predstavitelyami predprinimatel'skogo soobshchestva [Meeting with Representatives of the Business Community]', Novo-Ogaryovo, 26 March 2020.

${ }^{62}$ Vladimir Putin, 'Soveshchaniye s rukovoditelyami sub"yektov Federatsii po voprosam protivodeystviya rasprostraneniyu koronavirusnoy infektsii [Meeting with the Heads of the Subjects of the Federation on Countering the Spread of Coronavirus Infection]', Novo-Ogaryovo, 28 April 2020.

${ }^{63}$ DW News, 'Merkel: Coronavirus is Germany's greatest challenge since World War II' (18 March 2020), available at: \{https://www.dw.com/en/merkel-coronavirus-is-germanys-greatest-challenge-since-world-war-ii/a-52830797\} accessed 12 February 2021; Emmanuel Macron, 'Adresse aux Français du Président de la République Emmanuel Macron [Address to the French of the President of the Republic Emmanuel Macron]' (16 March 2020), available at: \{https://www.elysee.fr/ emmanuel-macron/2020/03/16/adresse-aux-francais-covid19\} accessed 12 February 2021.

${ }^{64}$ See, for example, Vladimir Putin, 'Osmotr bol'nitsy v Kommunarke [Inspection of the hospital in Kommunarka]', Kommunarka, 24 March 2020.

${ }^{65}$ Putin, 28 April 2020.

${ }^{66}$ See, for example, Vladimir Putin, 'Pozdravleniye s prazdnikom Paskhi [Congratulations on the Easter Holiday]', Novo-Ogaryovo, 19 April 2020; Vladimir Putin, "Vstrecha s uchastnikami obshcherossiyskoy aktsii "My vmeste" [Meeting with Participants of the All-Russian Initiative "We Are Together"]', Novo-Ogaryovo, 30 April 2020.

${ }^{67}$ See, for example, Putin, 17 March 2020; Putin, 28 April 2020.

${ }^{68}$ See, for example, Putin, 19 April 2020; Putin, 28 April 2020.
} 
Russia should prepare for all possible scenarios. ${ }^{69}$ While Putin makes it clear that he has control over the 'situation', he is not acting as a hyper-masculine strongman, and family-related imageries replace macho mannerisms and jargon that became his personal brand over the past two decades. $^{70}$

Securitising the COVID-19 outbreak, Putin projects hegemonic masculinity associated with traditional values of a heterosexual nuclear family. He distinguishes 'pregnant women and children', 'future mothers', 'elderly family members', as well as 'grandmothers and grandfathers' as the most vulnerable members of Russian society. ${ }^{71}$ He repeatedly highlights that the federal and regional governments are mobile, alert, and ready to 'support families', 'provide assistance to families', 'help family businesses to survive', and 'make sure that families are safe. ${ }^{72}$ By emphasising and continuously reinforcing the commitment to protect nuclear families rather than individuals, Putin portrays Russia as a tight-knit community where members depend on one another:

Our solidarity, concentration, responsibility, discipline, and willingness to support each other are simply irreplaceable. These qualities have allowed us to overcome many difficulties, like in a good and big family. ${ }^{73}$

These discursive constructions of the nation are best understood in Bonnie Mann's terms as 'performative enactments of national manhood in its sovereign mode'. ${ }^{74}$ Putin is acting as the head of the national household who is accepting the responsibility for all members of his large family. While he takes on the role of the caring and protective father and enacts this particular type of masculine domination, Russians are his subordinates and should embrace traditionally feminised virtues and values, such as care, benevolence, responsiveness, and attentiveness:

At all times, we resisted any misfortune together, joining forces. It is in traditions, literally in the blood of our people, in our genetic and cultural codes. And now we are together again. You prove this by your selfless work, your willingness to respond to pain, your willingness to care for those in need, to respond to other people's problems, to be where they are waiting for you and where your help is most needed. ${ }^{75}$

As evident from the quotes above, Putin often uses the first personal pronoun 'we', shortening the distance between himself and the Russians whom he addresses. He also effectively includes both himself and the audience in the same arena, creating a unified national body.

In another representative speech, Putin juxtaposes Russia to two fictional communities. The first one is the legendary Sparta where 'sick and crippled children were thrown from the Taygetus cliff. ${ }^{76}$ The second one is a tribe that abandons its elderly members when they become a burden from a short story The Law of Life, by Jack London. These two communities represent hypermasculinity. They are savage, violent, brutal, and deprived of empathy and compassion. Russia's Self comes into being when Putin discursively differentiates it from these hypermasculine

\footnotetext{
${ }^{69}$ See, for example, Putin, 17 March 2020; Putin, 28 April 2020.

${ }^{70}$ Valerie Sperling, 'Putin's macho personality cult', Communist and Post-Communist Studies, 49:1 (2016), pp. 13-23; Tatiana Mikhailova, 'Putin as the Father of the Nation', in Helena Goscilo (ed.), Putin as Celebrity and Cultural Icon (New York: Routledge, 2013), pp. 65-81.

${ }^{71}$ See, for example, Putin, 25 March 2020; Putin, 19 April 2020; Putin, 28 April 2020.

${ }^{72}$ Vladimir Putin, 'Meeting with heads of regions to combat the spread of coronavirus in Russia', Novo-Ogaryovo, 8 April 2020; Vladimir Putin, 'Soveshchaniye po voprosam bankovskogo kreditovaniya ekonomiki [Meeting on Bank Lending to the Economy]', Novo-Ogaryovo, 23 April 2020.

${ }^{73}$ Putin, 17 March 2020.

${ }^{74}$ Mann, Sovereign Masculinity, p. 164.

${ }^{75}$ Putin, 30 April 2020. See also Vladimir Putin, 'Soveshchaniye s polnomochnymi predstavitelyami Prezidenta [Meeting with Presidential Envoys]', Novo-Ogaryovo, 30 March 2020.

${ }^{76}$ Putin, 28 April 2020.
} 
imaginary Others by forcefully assuring that Russians have a different 'genetic code' to them. He then reinforces this message by using the first personal pronouns to emphasise collective responsibility and national unity in the face of a threat:

We learned from our ancestors completely different values. These are the values of mutual assistance and solidarity, and with them Russia has lived for a thousand years. And today, these values are the central pillar of our statehood. We got them together with Orthodox Christianity. These values also underlie other religions of the peoples of Russia - Islam, Buddhism, and Judaism. The philosophy of love for a human has helped us to survive for centuries. And today, the fate of other people is our responsibility. ${ }^{77}$

At the end of this emotional speech, Putin univocally uses 'we' to aggregate Russian citizens: 'I repeat it once again: our priority is people, their lives. Another choice is unacceptable for our people. I know that the absolute majority of us follow our conscience. ${ }^{78}$

According to Putin, in the face of an acute threat, the nation becomes a family, with himself being its patriarch. Describing his family, Putin implicitly connects Russianness to the legacies and values associated with the Russian Orthodox Church, while labelling representatives of other confessions - the majority of non-white Russian citizens - as 'the peoples of Russia'. This discursive construction of the national body is grounded in imperial hierarchical relations with both non-Russians inside and outside Russia. It used to sustain Putin's sexualised macho image $^{79}$ and now is instrumentalised as a means to appropriate Putin's new masculinity brand. Putin, who never has publicly shared his personal experiences of parenthood and fatherhood, paradoxically shifts from being the manliest Russian man to being the model Russian father. The appeal to paternalistic masculinity creates the fiction of a unified and homogenous Russian 'we' that is fully mobilised to repel the threat under Putin's guidance.

While economic hardship and depression that are associated with the pandemic feature prominently in Putin's statements, he repeatedly emphasises that human lives are more valuable than reopening businesses. In this context, sovereignty becomes synonymous with the ability of the state - embodied by Putin - to take good care of its frail people and shield them from the virus. Putin continuously emphasises that Russia has a fully equipped public health system that is operated by outstanding medical professionals possessing biomedical powers that enable them to save sick Russians and stop the spread of COVID-19. The citizens do not have to fight COVID-19 but rather passively receive support from their caregivers and follow directions. In this framework, the task of protecting Russia from the pandemic is the task for a wise patriarch rather than a warrior assertively sprinting from the defensive to the offensive.

Projecting the head of the family image, Putin calms down helpless and dependent members of his household. As a case in point, at the very end of an online meeting with members of the government and heads of Russia's regions, Putin suddenly goes off script, using two rather famous metaphors to describe the effect of the COVID-19 outbreak:

Everything passes, and this, too, shall pass away. Our country has repeatedly gone through severe trials: the Pechenegs tormented it, the Polovtsy, too - Russia dealt with everything. And we will also defeat this coronavirus scourge. Together we will overcome everything. ${ }^{80}$

\footnotetext{
${ }^{77}$ Ibid.

${ }^{78}$ Ibid.

${ }^{79}$ Valerie Sperling, Sex, Politics, and Putin: Political Legitimacy in Russia (Oxford: Oxford University Press, 2014), pp. 467; Arianna L. Nowakowski, 'Rewriting the Future: The Construction of Masculine Subjectivity Within Articulations of Russia's Post-Soviet National Idea’ (PhD dissertation, University of Denver, 2012), available at: \{https://digitalcommons. du.edu/etd/480\} accessed 25 September 2020, pp. 78-80.

${ }^{80}$ Putin, 8 April 2020.
} 
The first line of this articulate and layered piece carries a reference to the fable entitled 'Solomon's Seal', whereas the one about the Polovtsy and the Pechenegs is borrowed from an apocryphal speech of the famous Russian lawyer, Fyodor Plevako. Allegedly, Plevako got an old woman acquitted of stealing a teapot after he addressed the jury with the following words:

Russia has had to endure many troubles and challenges for more than one thousand years of its existence. The Pechenegs tormented her, the Polovtsy, the Tatars, and the Poles.... Russia endured everything, overcame everything, and only grew stronger as a result of those challenges. But now, an old woman stole an old teapot for thirty kopecks. This, of course, Russia will not endure, or else she will perish irrevocably. ${ }^{81}$

Consequently, Putin compares COVID-19 not with the invaders of the eleventh century but with a stolen teapot from an old judicial anecdote. ${ }^{82}$ His message to Russians and his team of executives emanates not bravado of a macho but the confidence of an experienced and prudent leader. Putin presents the COVID-19 outbreak as a comprehensive danger to the lives and livelihoods of Russians rather than an existential threat that might destroy Russia's sovereignty.

Over the past two decades, Putin has 'remasculinised' Russia and made his mark as a hypermasculine leader ever ready to attack his foes. His image became a function of public relations at home and abroad. ${ }^{83}$ As a result, he symbolises Russia and the key political projects of the 2000s and the early 2010s. ${ }^{84}$ Valerie Sperling elaborates that 'Putin made it clear that Russia had to embody - or be perceived as embodying - a set of traditionally masculine characteristics like independence and strength. ${ }^{85}$ Hence, the legitimation strategy of Putin's regime, according to Sperling, evolves around a 'macho personality cult'. ${ }^{86}$ She also argues that in the early $2010 \mathrm{~s}$ the Kremlin's public relations team briefly considered rebranding aging Putin (born in 1952) as the 'wise patriarch', yet Putin himself rejected this proposal. ${ }^{87}$ While in the late 2010 s and, especially after the annexation of Crimea, ${ }^{88}$ Putin's machismo has been in force, the discursive politics of securitising COVID-19 reveals that Putin's legitimacy evolves and relies on performances of fatherly protective masculinity.

The only prominent display of Putin's trademark machismo in the discursive politics of the pandemic is his surprise visit to a hospital treating COVID-19 patients on 24 March. Photographs capture Putin inspecting the hospital in a bright yellow full-body hazmat suit and fearlessly giving a long fleshy handshake to the head physician who showed him around. However, this militarised narrative of masculinity is outnumbered by Putin's performances (of varying persuasiveness) as a warm and compassionate father figure. Not only has Putin's rhetoric shifted away from macho masculinity but also the way he is visually presented to Russians has changed. For instance, Putin delivers his greetings to the Orthodox Christians on Easter sitting by a fireplace in a cosylooking living room next to a table set for tea and a traditional Russian Easter meal.

\footnotetext{
${ }^{81}$ Vikenty Versaev, Sobraniye sochineniy v 5 tomakh. Tom 4. [Collected Works in Five Volumes: Volume 4] (Moscow: Pravda, 1961), p. 356.

${ }^{82}$ Putin has already referred to this anecdote twice in the past in a similar context: in 2010 speaking of wildfires and in 2013 arguing with the minister of finances about the funding for Russian animation studios.

${ }^{83}$ Oleg Riabov and Tatiana Riabova, 'The remasculinization of Russia? Gender, nationalism, and the legitimation of power under Vladimir Putin', Problems of Post-Communism, 61:2 (2014), pp. 23-35 (pp. 27-9); Alexandra Novitskaya, 'Patriotism, sentiment, and male hysteria: Putin's masculinity politics and the persecution of non-heterosexual Russians', Norma, 12:3-4 (2017), pp. 302-18 (pp. 305-07).

${ }^{84}$ Andrew Foxall, 'Photographing Vladimir Putin: Masculinity, nationalism and visuality in Russian political culture', Geopolitics, 18:1 (2013), pp. 132-56.

${ }^{85}$ Sperling, Sex, Politics, and Putin, pp. 76-7.

${ }^{86}$ Sperling, 'Putin's macho personality cult', pp. 13-23.

${ }^{87}$ Sperling, Sex, Politics, and Putin, p. 44.

${ }^{88}$ Maryna Romanets, 'Virtual warfare: Masculinity, sexuality, and propaganda in the Russo-Ukrainian war', East/West: Journal of Ukrainian Studies, 4:1 (2017), pp. 159-77.
} 
Giving a comparative perspective, Putin refers to nameless 'other countries'. Even though Russia, according to him, is doing better than those 'other countries', it does not represent an exception and is struggling with the impact of the pandemic together with the rest of the world. ${ }^{89}$ Putin and other Russian officials do not present Russia as a trendsetter or a global leader. Accordingly, Russia is willing to provide humanitarian aid and act as a backstop for its strategic allies but is not willing to lead the fight against COVID-19 or take on a mission of restoring justice.

On the international stage, Russia is surrounded by friends, partners, and colleagues. Putin praises how 'Chinese friends' respond to the pandemic, ${ }^{90}$ is thankful to 'friends in Belarus' for their openness to cooperate, ${ }^{91}$ and wants Russia to learn from 'Italian colleagues'. ${ }^{92}$ Consequently, according to Putin, Russia's only antagonists are fictional hyper-masculinised communities. Other Russian officials, however, more bluntly and openly criticise the United States, portraying it as the main troublemaker. According to them, the United States sabotages international efforts to constrain the pandemic, pursuing its petit political interests. At the time when all countries should unite and consolidate, it foments ideological confrontation, spreading misinformation and attacking its political opponents, including Russia and China. For instance, Sergey Ryabkov, the Deputy Minister of Foreign Affairs, argues that 'despite the unprecedented nature of the challenge it faces' the United States is not willing to abandon 'the ideas that [it] is the only one who is always right in everything. ${ }^{93}$ Maria Zakharova, the spokesperson of the Ministry of Foreign Affairs, is 'horrified' with the lack of empathy for China shown by journalists from countries that 'not only consider themselves civilised but also profess high ideals of democracy and uphold human rights'. ${ }^{94}$ Elsewhere, Zakharova urges her colleagues in Washington 'to change [their] minds and unite with all humankind in front of the impending common threat'. 95

Russia is not competing openly against the United States for leadership, yet it reads the self-celebratory masculine rhetoric adopted by Trump as jeopardising Russia's own masculine claims and responds accordingly. In this framework, the United States is securitised as a potential threat because its aggressive and shortsighted foreign policy aggravates the challenges of the pandemic. This agitation reveals that, despite all the confidence that Putin demonstrates, Russia's masculinity is vulnerable, provisional, and requires regular and high maintenance.

\section{Conclusion}

Examining the securitisation of COVID-19 in the making, we show that both Trump and Putin instrumentalise hierarchical gendered identities to enforce it. They mobilise gendered narratives,

\footnotetext{
${ }^{89}$ See, for example, Putin, 17 March 2020; Putin, 26 March 2020.

${ }^{90}$ Vladimir Putin, 'Vstrecha s predstavitelyami obshchestvennosti v Cherepovetse [Meeting with Representatives of the Public in Cherepovets]', Cherepovets, 4 February 2020.

${ }^{91}$ Vladimir Putin, 'Soveshchaniye o situatsii s pavodkami i pozharami v regionakh [Meeting on the Situation with Floods and Fires in the Regions]', Novo-Ogaryovo, 27 April 2020.

${ }^{92}$ Vladimir Putin, 'Pozdravleniye s prazdnikom Paskhi [Congratulations on the Easter Holiday]', Novo-Ogaryovo, 19 April 2020 .

${ }^{93}$ Sergey Ryabkov, 'Interv'yu zamestitelya Ministra inostrannykh del [Rossii Interview with Deputy Minister of Foreign Affairs]', Mezhdunarodnaya zhizn' [The International Affairs] (17 April 2020), available at: \{https://interaffairs.ru/news/ show/26067\} accessed 25 September 2020.

${ }^{94}$ Maria Zakharova, 'Brifing. O merakh v svyazi so vspyshkoy v Kitaye novoy koronavirusnoy infektsii [Press Conference: On the Outbreak of a New Coronavirus Infection in China]', Ministry of Foreign Affairs of the Russian Federation, 12 February 2020.

${ }^{95}$ Maria Zakharova, 'Brifing. O vklade Kuby v mezhdunarodnyye usiliya v bor'be s pandemiyey koronavirusa [Press Conference. On Cuba's Contribution to International Efforts to Combat the Coronavirus Pandemic]', Ministry of Foreign Affairs of the Russian Federation, 27 March 2020.
} 
imageries, and practices to affirm particular understandings of the threat and create a homogeneous national 'we', portraying themselves as its protectors and guardians.

The COVID-19 pandemic arrived at a contentious political moment for both Trump and Putin. Both were forced to defend their leadership and did so by proclaiming their masculinity. Throughout January and February 2020, Trump faced a media-scorned impeachment trial set to weaken his political authority and jeopardise his future contention for the presidency. After being acquitted on all charges, Trump's presidential campaign faced increasing political pressure to outperform his Democrat opponents amid the pandemic. To assuage the possibility of a political loss, Trump deployed hegemonic masculine practices and militarised rhetoric to respond to his purported 'unmanning' from COVID-19. These discursive tactics rebuild and reassert Trump's sovereign masculinity on both the domestic and global stage, marking his attempt to securitise COVID-19 and mobilise the 'whole-of-America' under his leadership.

In Russia, a proposal of substantial amendments to the Constitution, which above all would potentially extend Putin's rule to 2036, passed by the lower house of Parliament in mid-January 2020. To approve them, Putin needed a nationwide referendum. At the same time, his regime was weakened by the international oil war. The decline of Russia's fragile economy was further exacerbated by a steep drop in crude oil prices between January and May. Against this backdrop, Putin uses hegemonic paternalistic masculinity amid the early outbreak of the COVID-19 crisis to justify statist policies, the centralisation of power, and political authoritarianism as a legitimate means of governance.

The masculinity performed by Trump and Putin is toxic, inasmuch as it (re)produces and nourishes state-inspired nationalism and white supremacy. On the domestic level, their gendered securitisation discourses atomise American and Russian citizens, imposing on them subjugating features of a homogenous national 'we' and creating new exclusionary boundaries along the lines of race and ethnicity. As a case in point, Trump employs hegemonic discourses to reconceptualise the United States as a white, masculine entity. In stark terms, Trump's gendering of the nation constructs fictionalised divisions between who belongs to the 'we' and who is framed as the excluded Other. These discourses not only formulate the pandemic as a health crisis but also elevate it to that of a racialised security threat, capable of compromising the purity of the United States. As for the Russian case, the brand of hegemonic masculinity reproduced by Putin normalises the racialisation of Russian nationalism and further anchors Russianness in its ethnic and religious terms. Moreover, Putin fosters paternalistic domination over women by rendering them as passive victims of the pandemic to be protected and guided.

Both Trump and Putin elevate the COVID-19 outbreak to a global threat. However, while Trump turns his response to the pandemic into a competition that the United States is destined to win, Putin focuses on cooperation under collective responsibility. Trump wants the United States to get ahead of other countries. Putin claims that Russia will learn from other countries and analyse their experience carefully while setting an example of the proper ethical conduct for the rest of the world. As much as these two narratives are at odds with each other, they both create multiple dichotomies where Others are represented as subordinated to the national Self and thus are either feminine or hyper-masculine. In the case of feminisation, Others are presented as passive, weak, and poorly organised. Hyper-masculine Others are aggressive, irrational, egotistical, and competitive. Both are portrayed as dangerous and threatening to the international community at large. These tight hierarchical dichotomies normalise and fuel the great power confrontation and prevent the international community from engaging in a constructive dialogue and synergetic planning to respond to the pandemic.

In both cases, political leaders enacted hierarchical gendered identities in the securitisation of COVID-19, sustaining their national manhoods and bolstering their legitimation strategy. A year down the road, it is evident that Trump's and Putin's illusionary projections of the 'guardian of the nation' did not translate into effective policy responses that alleviated the threat of COVID-19. Both the United States and Russia are among the top ten most affected countries by COVID-19 
worldwide. ${ }^{96}$ For the United States, 2020 was the deadliest year in its history, with deaths associated with COVID-19 reaching 473,000. ${ }^{97}$ Russia officially recorded more than 358,000 excess deaths between April and December 2020, ${ }^{98}$ with almost 100 per cent of these deaths in some regions attributed to COVID-19. ${ }^{99}$ These numbers demonstrate that both Trump and Putin failed many of their citizens, letting the deadly virus run wild.

However, bringing to the fore Trump's and Putin's convergent securitising discourses, we do not target the failure of their securitising moves. Rather, we problematise Trump and Putin's deployment of masculinity as a tool in securitisation that led both leaders to dangerously exert hegemonic masculinity in times of uncertainty. In the United States, Trump dispelled contrasting emotions of fear and security to quell the pandemic's threat to American sovereignty, invulnerability, and global dominance, while concurrently cementing his position as the nation's protector. In Russia, Putin drew on the idealised heteronormative concept of the nuclear family to frame himself as the nation's patriarch and legitimise his authoritarian regime. As such, the process of securitising is not uniform but instead socially and culturally specific. We do not argue that a resurgence of hegemonic masculinity is intrinsic to securitisation or that securitisation is simply a ploy used by all national leaders during a crisis to reassert their nation's sovereignty. Yet, our findings show that both Trump and Putin - two very notable and influential politicians in the international arena, to say the least - virtually turn masculinity into the means of securitising COVID-19. Overall, studies as the one we present here demonstrate how implicit and explicit references to masculinity in the process of securitisation confirm it as the political norm and thus naturalise the systemic effects of toxic gendered practices that permeate both Trump's and Putin's quests for power.

We hope that our study inspires other feminist scholars to further investigate how different actors securitise COVID-19 in various contexts across the world and, as a way of concluding, we would like to propose three possible directions for future research. Firstly, the United States and Russia embody the masculine in international relations. Their great power ambitions and competitive strivings are embedded in what V. Spike Peterson terms 'gendered hierarchies', which systematically reproduce a discursive 'denigration of the feminine' together with an ultimate glorification of hegemonic masculinities. ${ }^{100}$ Following Peterson's logic, how do states that are not (or at least less) obsessed with global domination securitise COVID-19? Future comparative studies could bring to the fore broader questions about the very nature of securitisation. Specifically, to what extent does masculinity always dominate the process of securitising? Secondly, while our study is preoccupied with state actors, (de)securitising moves of non-state actors deserve attention too. For example, how are gendered imaginaries and narratives of the pandemic wielded in the conduct of the World Health Organisation and the United Nations? Finally, since the COVID-19 pandemic is a truly global crisis, are there any global gendered narratives and imageries that capture it? How will this crisis make apparent the heterosexualised gendered concepts of threat and security? The more we learn about the links between gendered discursive politics and securitisation, the more comprehensive our understanding will be of

\footnotetext{
${ }^{96}$ Johns Hopkins University and Medicine, 'Mortality Analyses: How Does Mortality Differ across Countries?' (13 February 2021), available at: \{https://coronavirus.jhu.edu/data/mortality\} accessed 13 February 2021.

${ }^{97}$ Centres for Disease Control and Prevention, 'COVID Data Tracker' (12 February 2021), available at: \{https://covid.cdc. gov/covid-data-tracker/\#datatracker-home\} accessed 13 February 2021.

${ }^{98}$ Federal State Statistics Service, 'Obshchiye itogi yestestvennogo dvizheniya naseleniya Rossiyskoy Federatsii [The Summary of the Natural Movement of the Population of the Russian Federation]' (8 February 2021), available at: \{https:// rosstat.gov.ru/storage/mediabank/TwbjciZH/edn12-2020.html\} accessed 13 February 2021.

${ }^{99}$ The Department of Health of Moscow, 'Depzdrav Moskvy opublikoval dannyye po smertnosti ot koronavirusa za dekabr' 2020 goda [The Department of Health published coronavirus mortality data for 2020]' (8 February 2021), available at: \{https://mosgorzdrav.ru/ru-RU/news/default/card/5321.html\} accessed 13 February 2021.

${ }^{100}$ V. Spike Peterson, 'Sexing political identities / nationalism as heterosexism', in Sita Ranchod-Nilsson and Mary Ann Tétreault (eds), Women, States, and Nationalism: At Home in the Nation? (New York: Routledge, 2000), p. 58.
} 
how power reproduces itself and how particular readings of (in)security become appropriate, while others are silenced.

Acknowledgements. We thank Licia Cianetti, who gave helpful suggestions on the early draft of our article, and the two anonymous reviewers for offering insightful and thoughtful comments.

Anna Kuteleva is a postdoctoral research fellow at the School of International Regional Studies at the National Research University Higher School of Economics (Russia). Anna holds a $\mathrm{PhD}$ in Political Science from the University of Alberta (Canada). Her research is located in a broad constructivist tradition of IR and focuses on the nexus between politics and sociocultural contexts in international relations, with particular interests in politics of security, energy politics, China, and Russia.

Sarah J. Clifford is an MSc student in Political Science at the University of Copenhagen (Denmark). Her main research interests centre on international relations and gender. Her Master's project explores the intersections of American militarised masculinities, identity politics, and education policies. Prior to relocating to the University of Copenhagen, Sarah studied Political Science and worked as a Research Assistant for the China Institute and the Faculty of Education at the University of Alberta (Canada).

Cite this article: Kuteleva, A., Clifford, S. J. 2021. Gendered securitisation: Trump's and Putin's discursive politics of the COVID-19 pandemic. European Journal of International Security 6, 301-317. https://doi.org/10.1017/eis.2021.5 